УДК 338.46

DOI: https://doi.org/10.37320/2415-3583/12.9

Костинець В.В.

кандидат економічних наук, доцент кафедри бізнес-економіки та туризму, Київський національний університет технологій та дизайну ORCID: http://orcid.org/0000-0002-4222-7620

\title{
СПЕЦИФІКА ЗАСТОСУВАННЯ ТУРИСТИЧНОГО ЗБОРУ
}

Стаття присвячена встановленню спеиифіки застосування туристичного збору в Украӥні в посткарантинний період на основі світового досвіду. Автор статті розглядає питання застосування туристичного збору в низиі провідних туристичних дестинацій Свропи та світу, акцентуючи увагу на підходах до розрахунку $і$ нарахування туристичного збору. Автор підкреслює чотири способи обчислення та справляння туристичного збору. Окрім того, окремо автор наголошує на тому, щуо низка європейських краӥн відзначають необхідність тимчасового скасування стягнення туристичних зборів із метою якнайшвидиого відновлення міжнародних туристичних прибуттів після скасування обмежень і відкриття кордонів. Автор зазначає, щео застосування туристичного збору в Україні $є$ нагальною потребою через необхідність розвитку туристичного сектору нашої економіки, підтримки та розвитку курортної та туристичної інфраструктури, особливо в курортних регіонах. Водночас, із погляду розвитку туристичної галузі, як внутрішнього, так і в'їзного туризму, доцільно розглянути питання про тимчасове скасування туристичного збору з метою заохочення потенційних туристів здійснювати туристичні поӥздки в Украйну.

Ключові слова: туристичний збір, туристичний внесок, туристичні дестинації, сві-товий досвід, туристичні прибуття.

Постановка проблеми. Тенденція використання туристичного збору сьогодні зберігає свою актуальність у низці країн світу, в тому числі і в Україні. Водночас у зв'язку зі спалахом коронавірусної інфекції COVID-19, подальшим оголошенням світової пандемії, закриттям кордонів та обмеженням міжнародних перевезень, що в результаті призвело до суттєвих втрат туристичного сектору, більшість країн світу опинилися перед вибором: або підняти ставки туристичного збору
3 метою наповнення бюджетів усіх рівнів, насамперед місцевих, у повному обсязі, або тимчасово скасувати туристичний збір як обов'язковий платіж із метою підвищення рекреаційної привабливості країни після зняття карантинних обмежень. На користь останньої позиції свідчить той факт, що вже зараз деякі європейські дестинації скасували туристичні збори через спалах коронавірусу і таким чином планують відновити потоки туристів після скасування обмежень і відкриття 
кордонів. Так, у Венеції перенесли запуск податку на в'їзд на 2021 р. замість його запровадження 3 червня 2020 р. Влада Барселони призупинила збір туристичного податку до вересня 2020 р., хоча на початку року його ставки піднялися. У Португалії скасували туристичний внесок за відвідування курорту Алгарве. Насамперед французька влада призупинила збір частини податків і платежів, які додаються під час купівлі авіаквитків, у тому числі екологічного податку. У Хорватії туристичний збір скасували на період літнього туристичного сезону, водночас не виключається ймовірність, що така політика продовжиться ще на осінні місяці. Податок на проживання в Туреччині, який повинен був сплачуватися туристами з 1 квітня 2020 р., відклали до 1 січня 2021 р. 3 такою ж пропозицією виступили готельєри Греції, але нині офіційне рішення 3 цього питання відсутнє.

Для України туристичний збір є певною новацією останніх років, попри це вже сьогодні Міністерство культури та інформаційної політики закликає сьогодні законодавчий орган влади розглянути законопроект Закону України «Про внесення змін до деяких законодавчих актів щодо державної підтримки сфери культури, креативних індустрій, туризму, малого та середнього бізнесу у зв'язку з дією обмежувальних заходів, пов'язаних із поширенням коронавірусної хвороби (COVID-19)», згідно 3 яким, зокрема, пропонується скасування туристичного збору до кінця 2020 р. Виходячи 3 вищевикладеного, в межах дослідження науковий інтерес становить вивчення досвіду зарубіжних країн щодо регламентації відносин у сфері застосування туристичного збору і можливості його адаптації до вітчизняних умов у посткарантинний період.

Аналіз останніх досліджень i публікацій. Питанню застосування туристич-ного збору присвячена досить обмежена кількість наукових доробків як зарубіжних, так і вітчизняних учених. Так, низка науковців, у тому числі Ю. Міщенко та А. Крисоватий, здебільшого досліджують питання удосконалення нормативно-правової бази, підвищення ефективності та спрощення системи адміністрування податків, зборів та інших обов'язкових платежів, а також розширення бази оподаткування [4]. Праці С. Скибенко присвячені дослідженню основних проблем чинної регіональної податкової політики, що стосується сплати туристичного збору [6, с. 317]. Н. Гуручерн та Т. Сінклейр [9, с. 1-37] розглядають питання економічного ефекту туристичних зборів 3 погляду добробуту місцевого населення. Я. Казюк [2, с. 385] пропонує у своїх дослідженнях у рішеннях місцевих рад щодо встановлення туристичного збору визначати перелік податкових агентів, у тому числі і у разі співпраці з квартирно-посередницькими організаціями визначати перелік приватних осіб, яким надано право розміщувати у себе туристів, iз зазначенням закріпленої за ними кількості ліжкомісць, а також розраховувати середній рівень цін за проживання. Нерозкритим залишається питання регламентації відносин у сфері застосування туристичного збору щодо можливості його адаптації до вітчизняних умов у посткарантинний період. Відповідно, наукова новизна цього дослідження полягає у розв'язанні важливого науково-прикладного завдання, а саме в межах цієї статті розроблено науково-практичні засади справ- ляння туристичного збору в посткарантинний період в Україні, запропоновано тимчасове скасування туристичного збору 3 метою стимулювання потенційних туристів до здійснення туристичних подорожей Україною на період до кінця 2020 р. та обгрунтовано наукові пропозиції щодо розроблення та реалізації змін щодо бази справляння туристичного збору після його відновлення з 2021 р., які враховують чинники та особливості посткарантинного періоду.

Метою статті $є$ встановлення специфіки застосування туристичного збору в Україні в посткарантинний період на основі світового досвіду.

Виклад основного матеріалу дослідження. Всю множинність платежів, які застосовуються в туристичній галузі, можна об'єднати у декілька груп [1, с. 150]:

1) податки та збори, які мають загальний характер і застосовуються не тільки до туристичної, а й до інших галузей економіки;

2) необгрунтовані спеціальні податки, які не мають відновлювального призначення і невиправдано збільшують вартість туристичних послуг;

3) спеціалізовані туристичні збори, які насамперед мають відновлювальний характер і виступають компенсацією за користування туристичною інфраструкту-рою та культурними благами певного регіону. Основною перевагою туристичного збору є той факт, що кошти від його сплати спрямовуються до місцевого бюджету, а потім використовуються для розвитку туристичної інфраструктури, в тому числі на забезпечення мандрівникам більш комфортних умов проживання, реставрацію пам'яток, благоустрій, проведення фестивалів, спортивних заходів тощо.

Як показує практика, розмір туристичного збору в кожному муніципалітеті встановлює місцева влада, навіть на території однієї країни або регіону величина збору може змінюватися від міста до міста, однак $\epsilon$ всього чотири способи розрахунку i нарахування туристичного збору:

1) фіксована сума туристичного збору встановлюється на одного туриста, загальна сума збору залежить від кількості ночей, які він проведе в засобі розміщення (збір нараховується на кожного туриста, який проживає в номері готелю);

2) сума туристичного збору залежить від кількості ночей, проведених у засобі розміщення, однак його ставка не залежить від кількості осіб, які проживають у номері;

3) сума туристичного збору включена у вартість номера і нараховується відразу під час бронювання за весь термін перебування у готелі;

4) сума туристичного збору розраховується як відсоток від вартості номера.

У більшості європейських міст найбільш популярним та застосовуваним є перший підхід: суму туристичного збору стягують із кожного туриста залежно від того, скільки ночей він буде жити в готелі, однак рішення про включення суми туристичного збору у вартість номера або стягнення його окремо приймається кожним об'єктом розміщення самостійно. Крім того, розмір туристичного збору може змінюватися залежно від того, який тип об'єкта розміщення вибирає турист - апартаменти, номер у готелі або хостелі, а також безпосередньо від категорії готелю. 
Звернемося до світового досвіду застосування туристичного збору. Наприклад, в деяких містах Німеччини турист, сплачуючи туристичний збір, отримує картку туриста, яка дає низку привілеїв, таких як знижки на відвідування музеїв, ресторанів, безкоштовний проїзд у громадському транспорті, безкоштовне користування деякими курортними закладами, низка безкоштовних послуг тощо. Слід зазначити, що коріння німецького туристичного збору сягають Середньовіччя, а його поява пов'язана 3 одним із найвідоміших курортів Німеччини - БаденБаденом, в якому з 1507 р. із приїжджих стали стягувати так званий курортний пфеніг за користування термальними джерелами. Більш широко в Німеччині туристичний збір поширився в XIX столітті. Так, спеціальний закон про правила стягнення податку 3 відпочиваючих був прийнятий ще в 1893 р. [3] Нині ставка туристичного збору в Німеччині коливається від 0,50 євро до 4 євро за ніч, або 7,5\% від вартості готельного номеру. При цьому в німецькому Мюнхені туристичний збір відсутній.

У 2011 р італійський уряд ухвалив закон, що дає змогу містам вводити туристичний податок на проживання у приймаючих структурах у розмірі не більше 7 євро за людину за ніч [10]. Слід зазначити, що встановлення та стягнення туристичного податку в Італії $\epsilon$ прерогативою муніципалітету. Однак з огляду на те, що податок стягується не готелем, а муніципалітетом, його повинні оплачувати i ті, хто проживає в готелях за договором безкоштовно: супроводжуючі груп, водії туристичних автобусів тощо. Податок сплачується самими туристами під час заїзду в готель чи виїзду, а виручені кошти відраховуються до міських бюджетів і спрямовуються на розвиток туристичної інфраструктури та сфери послуг. Нині податок введений більш ніж у 20 містах і курортних зонах Італії, зокрема в Римі, Флоренції, Венеції, Падуї, Ріміні, Генуї, Пізі, Монтекатіні, Сорренто, на озерах Комо, Гарда, Маджоре, на о. Сардинія тощо.

32018 р. туристичний збір впроваджено також у Греції, сума його варіюється залежно від категорії засобу розміщення. Так, 0,5 євро туристичного збору передбачено в апартаментах та готелях категорії 1-2*, 1,50 євро - в тризіркових готелях, 3 євро - в чотиризіркових готелях, 4 євро - в готелях категорії $5 *$ за номер [10].

У Франції туристичний податок був введений ще в 1910 р. Його розмір вста-новлюється на рівні комун і може бути як постійним, так і сезонним, проте представницькі органи департаментів можуть стягувати 3 туристів додатковий податок, розмір якого становить $10 \%$ від встановленого владою комун. Від сплати податку звільняються туристи, які не досягли повнолітнього віку, а також сезонні мігранти. Так, ставка податку варіюється залежно від категорії готелю і становить від 0,2 євро до 8 євро за ніч із людини [8].

Уряд Нідерландів дозволяє містам вводити туристичний податок на проживання у приймаючих структурах, який оплачується самими туристами під час заселення або виселення з готелю. При цьому виручені кошти відраховуються до міських бюджетів і спрямовуються на розвиток туристичної інфраструктури та сфери туристичних послуг. У всіх містах і регіонах податкові тарифи (в Амстердамі - 5,5\% від вартості номера за ніч, у невеликих містах податок може бути 1,5 євро за ніч) і терміни їхньої дії встановлюються адміністрацією та можуть змінюватися [10].

Також у зв'язку з нестачею фінансів на розвиток туристичного сектору влада В'єтнаму з 1 січня 2014 р. запровадила туристичний податок, який сплачується в розмірі 1 долара за добу перебування. Для відвідування Домініканської Республіки мандрівникам, які прибувають в аеропорт Пуерто Плата, потрібно заповнити картку туриста і сплатити податок в аеропорту в розмірі 10 доларів під час в'їзду в країну і 10 доларів під час виїзду (звільняються від сплати податку діти молодше двох років і транзитні пасажири). У Йорданії стягується податок з індивідуальних туристів під час виїзду, якщо туристи перебували в країні більше доби, в розмірі 5 йорданських динарів. 3 лютого 2014 року кожний турист, що в'їжджає на Мальдіви, незалежно від віку, оплачує Bed Тах (податок на розміщення) в сумі 8 доларів на добу за людину. У Берні (Швейцарія) туристичний податок складається з трьох частин, таких як: податок на проживання, курортний збір, а також транспортний збір, який сплачується одночасно в готелі і становить від 2,5 до 6 франків [8].

Що стосується України, то статтею 268 Податкового кодексу України визна-чено, що платниками збору є громадяни України, іноземці, а також особи без громадянства, які прибувають на територію адміністративно-територіальної одиниці, на якій діє рішення сільської, селищної та міської ради про встановлення збору, та отримують (споживають) послуги з тимчасового проживання (ночівлі) із зобов'язанням залишити місце перебування в зазначений строк [5]. Станом на 2020 р. максимальний розмір туристичного збору встановлено на рівні 23,62 грн для внутрішнього туризму та 236,15 грн для в’їного туризму [7]. Загалом же застосування туристичного збору в Україні $є$ нагальною потребою, зумовленою потребою розвитку туристичного сектору економіки нашої країни, підтримки і розвитку курортної і туристичної інфраструктури, особливо в курортних регіонах.

Пропозиції автора детерміновані ситуацією на ринку туристичних послуг, що була спричинена наслідками протиепідемічних карантинних заходів. Спираючись на закордонний досвід європейських країн, iз погляду розвитку як внутрішнього, так і в’ізного туризму вважаємо доцільним рекомендувати тимчасове скасування туристичного збору з метою стимулювання потенційних туристів до здійснення туристичних подорожей Україною, адже саме виважена податкова політика в посткарантинний період є одним із найважливіших кроків до залучення інвестицій у туристичну галузь України та зростання іï привабливості на міжнародному рівні. Тимчасове скасування туристичного збору, на думку автора, є доцільним на шестимісячний період з 1 липня 2020 р. до 1 січня 2021 р. Вибраний період визначений прогнозами експертів ринку туристичних послуг стосовно часу поступового відновлення туристичних прибуттів як із-за кордону, так і всередині країни. Таким чином, тимчасове скасування туристичного збору рекомендоване як для резидентів, так і для нерезидентів країни. 
Відновлення справляння туристичного збору доцільно запланувати 31 січня 2021 р. При цьому пропонуємо дещо змінити базу справляння туристичного збору. Станом натепер такою базою в Україні є загальна кількість діб проживання, а туристичний збір стягується 3 кожного туриста за кожну добу проживання у закладі розміщення незалежно від кількості діб. Вважаємо більш доцільним та привабливим для розвитку туризму справляння туристичного збору залежно від кількості ночей, проведених у засобі розміщення, проте незалежно від кількості осіб, які проживають у номері, тобто встановлення розміру туристичного збору фактично не з особи, а з кількості місць у номері закладу розміщення.

Водночас після відновлення справляння туристичного збору за умови позитивної динаміки розвитку українського туризму необхідно врахувати, що єдиним можливим варіантом удосконалення туристичного збору є збільшення особистої зацікавленості туристів та податкових агентів у розвитку туристичної інфраструктури і чіткому простежуванні надходжень від цього платежу. Зокрема, підвищенню рентабельності туристичної галузі може сприяти встановлення чіткої взаємозалежності між матеріальним забезпеченням відповідної історичної чи культурної пам'ятки та іï туристичною привабливістю для іноземного туриста. Так, кошти необхідно витрачати насамперед на позиціонування і рекламно-інформаційну підтримку туристичних дестинацій, які знаходяться поблизу від інфра- структурних об'єктів, зручних транспортних розв'язок чи великих міст. Особливу увагу потрібно в подальшому зосередити на покращенні матеріально-технічної бази місць розташування таких пам'яток.

Висновки. Сьогодні туристична діяльність $\epsilon$ невід'ємною складовою части-ною необхідних економічних посткарантинних перетворень, в основі яких має перебувати повний і гармонійний розвиток особистості, право людини на повагу до гідності та індивідуальності, а також моральних цінностей народів. Аналіз сучасного стану туризму в багатьох країнах показує, що його розвиток має супроводжуватися зусиллями держав у сприянні програмам розвитку внутрішнього туризму, які можуть бути ефективно реалізовані за наявності достатніх коштів і джерел фінансування, що нині у багатьох країнах на достатньому рівні відсутнє. Для вирішення проблем фінансування туристичного сектору як альтернативний захід і вводиться туристичний збір, покликаний акумулювати кошти, що надійшли від туристів, і використовувати їх із метою розвитку курортної і туристичної інфраструктури тих регіонів, на території яких він введений. Водночас під час проведення подальших розвідок у цьому аспекті варто врахувати, що в період стагнації туристичної галузі слід залучити світовий досвід грамотного регулювання застосування туристичного збору та його тимчасового скасування як інструменту опосередкованого стимулювання зростання туристичних прибуттів.

\section{Список використаних джерел:}

1. Евсикова Е.В. Систематизация основных подходов к определению понятия «налоговые правоотношения». Евразийский юридический журнал. 2015. № 4 (83). С. 149-152.

2. Казюк Я.М. Сучасний стан та шляхи вдосконалення механізмів надходжень місцевих податків і зборів. Теорія та практика державного управління. 2012. № 3. С. 382-390.

3. Курортный сбор в Германии. URL: http://turbina.ru/blogs/view/Kurortnyy-sbor-v-Germanii-101810/ (дата звернення 08.05.2020)

4. Міщенко Ю.В., Крисоватий А.І. Кластерна модель туризму: польський досвід і можливості його використання в Україні. URL: http://www.frtu.org.ua/content/view/4244/65/ (дата звернення 05.05.2020)

5. Податковий кодекс України: Відомості Верховної Ради України. 2011. № 13-14, № 15-16, № 17. Ст. 112.

6. Скибенко С.Т., Розвадовська О.О. Роль туристичного збору у фінансуванні регіонів. Науковий вісник Полтавського університету економіки і торгівлі. 2013. № 2 (58). С. 315-319.

7. Сколько турсбора будут платить в 2020 году URL: https://interbuh.com.ua/ru/documents/onenews/135560 (дата звернення 10.05.2020)

8. Туристический налог в разных странах. URL: https://city.travel/info/tourtaxes (дата звернення 05.05.2020)

9. Gooroochurn N., Sinclair T. The Welfare Effects of Tourism Taxation. Christel DeHaan Tourism and Travel Research Institute. 2003. Pp. 1-37.

10. Tourist tax in Europe 2020: what you will pay in Spain, Italy and other hotspots. URL: https://www.lovemoney.com/ guides/52231/tourist-tax-in-europe-what-you-will-pay-in-spain-italy-and-other-hotspots (accesed 25 April 2020)

\section{References:}

1. Evsikova, E.V. (2015). Sistematizatsiya osnovnykh podkhodov k opredeleniyu ponyatiya «nalogovye pravootnosheniya» [Systematization of the main approaches to the definition of the concept of "tax legal relations"]. Evraziyskiy yuridicheskiy zhurnal, vol. 4, pp. 149-152.

2. Kazjuk, Ja.M. (2012). Suchasnyj stan ta shljakhy vdoskonalennja mekhanizmiv nadkhodzhenj miscevykh podatkiv i zboriv [The current state and ways to improve the mechanisms of local taxes and fees]. Teorija ta praktyka derzhavnogho upravlinnja, vol.3. pp. 382-390.

3. Kurortnyy sbor v Germanii [Resort tax in Germany]. URL: http://turbina.ru/blogs/view/Kurortnyy-sbor-v-Germanii-101810/ (accesed 8 May 2020)

4. Mishhenko, Ju.V., Krysovatyj, A.I. Klasterna modelj turyzmu: poljsjkyj dosvid i mozhlyvosti jogho vykorystannja v Ukrajini [Cluster model of tourism: Polish experience and possibilities of its use in Ukraine]. URL: http://www.frtu.org.ua/content/view/4244/65/ (accesed 5 May 2020)

5. Podatkovyj kodeks Ukrajiny [Tax Code of Ukraine] Vidomosti Verkhovnoji Rady Ukrajiny. 2011. № 13-14, № 15-16, № 17. St.112.

6. Skybenko, S.T., Rozvadovsjka, O.O. (2013). Rolj turystychnogho zboru u finansuvanni reghioniv [The role of tourist tax in the financing of regions]. Naukovyj visnyk Poltavsjkogho universytetu ekonomiky i torghivli, vol. 2 (58), pp. 315-319. 
7. Skol'ko tursbora budut platit' v 2020 godu [How much travel collection will pay in 2020] URL: https://interbuh.com.ua/ru/ documents/onenews/135560 (accesed 10 May 2020)

8. Turisticheskiy nalog v raznykh stranakh. URL: https://city.travel/info/tourtaxes (accessed 05 May 2020)

9. Gooroochurn, N., Sinclair, T. (2003). The Welfare Effects of Tourism Taxation. Christel DeHaan Tourism and Travel Research Institute, pp. 1-37.

10. Tourist tax in Europe 2020: what you will pay in Spain, Italy and other hotspots. URL: https://www.lovemoney.com/ guides/52231/tourist-tax-in-europe-what-you-will-pay-in-spain-italy-and-other-hotspots (accesed 25 April 2020)

\author{
Kostynets Valeriia \\ Kyiv National University of Technology and Design
}

\title{
SPECIFICITY OF APPLICATION OF TOURIST TAX
}

The article is devoted to establishing the specificity of the application of tourist tax in Ukraine in the post-quarantine period on the basis of world experience. The author of the article considers the application of tourist tax in a number of leading tourist destinations in Europe and the world, focusing on approaches to the calculation and calculation of tourist tax. The author emphasizes four ways to calculate and calculate the tourist tax: fixed amount of tourist tax is set for one tourist, the total amount of the fee depends on the number of nights he will spend in the accommodation (the fee is charged for each tourist staying in a hotel room); amount of tourist tax depends on the number of nights spent in the accommodation, but its rate does not depend on the number of people staying in the room; amount of tourist tax is included in the room rate and is charged immediately upon booking for the entire stay in the hotel; amount of tourist tax is calculated as a percentage of the room rate. According to the results of the study, the author concluded that to solve the problems of financing the tourism sector as an alternative measure and introduced a tourist tax designed to accumulate funds from tourists and use them to develop resort and tourism infrastructure in the regions where it is introduced. The author notes that the use of tourist tax in Ukraine is an urgent need due to the need to develop the tourism sector of our economy, support and development of resort and tourist infrastructure, especially in resort regions. At the same time, from the point of view of the development of the tourism industry, both domestic and inbound tourism, it is advisable to consider the issue of temporary abolition of the tourist tax in order to encourage potential tourists to make tourist trips to Ukraine. Besides, the author emphasizes that a number of European countries note the need to temporarily abolish the collection of tourist fees in order to restore international tourist arrivals as soon as possible after the abolition of restrictions and the opening of borders. The abolition of the tourist tax can be a tool to indirectly stimulate the growth of tourist arrivals.

Key words: tourist tax, tourist contribution, tourist destinations, world experience, deter-minants.

JEL classification: H20, O10, G28 